\section{STANLEY'S AFRICAN DISCOVERIES}

M R. STANLEY, in the work he has already done, has made a substantial contribution to African geography, and the last letters from him which have recently appeared in the Daily Telegraph raise eager hopes that shortly we shall hear of his having aicomplished work of even greater value. We do not propose to recapitulate the narrative with which most of our readers must be familiar from the interesting letters in the Telegraph, but briefly to point out, with the aid of the accompanying map, how much Mr. Stanley has in these letters added to our knowledge. Of course our map does not pretend to rigid accuracy, its object being simply to show Mr. Stanley's route, the amended outline of the Victoria Nyanza, and the main features of the country traversed by him. It is not our desire to take up space with conjectural geography, nor to reconcile Mr. Stanley's statements with those of previous travellers, nor to discuss what is likely to be the tendency of future discoveries. All this seems to us unnecessary at present, as there is every probability that we shall not have long to wait for accurate and full information from the various travellers that are now in the field.

One of the most satisfactory parts of Mr. Stanley's work is undoubtedly his circumnavigation of the Victoria Nyanza, and the filling in of its outline with something approaching to accuracy. Previous to Mr. Stanley's visit we were dependent mainly on conjecture for the configura. tion and dimensions of this important lake, supplemented by the observations at one or two points of Speke, on whose name Mr. Stanley's discoveries have shed additional glory. Anyone comparing the map which we have drawn up from Stanley's information with that of Speke will be able to see how much the latest traveller has done. The outline of the shore all round is given with what we must regard as a fair ap proach to accuracy, to be supplemented ere long, we hope, by careful survey. The long branch lake on the north-east has been cut off, probably to become a separate lake or marsh further east; the eastern shore has been brought considerably westwards, while the southern and western shores have received important modifications. The "numerous islands" of Speke's map have many of them been visited and most of them been seen and named, and are found to extend almost all round the lake at a short distance from the shore. The names at least of many of the tribes that inhabit the shores and the islands have been obtained, and not a few details concerning their customs and physique. Stanley's account of his visits to Mtesa are in the highest degree interesting, and cannot but raise our admiration of the excellent diplomacy of the determined commissioner of the Telegraph and the Herald. As to the extent of the lake, the conjecture that it is about 1,000 miles in circumference is probably not far from the mark; from the observations of Stanley its height above sea-level is calculated to be 3,800 feet, very near to one, at least, of the observations obtained by Speke.

Probably after the circumnavigation of the Victoria Nyanza, the most satisfactory piece of work done by Stanley has been the tracing of a large portion of the lacustrine river Kagera, the same which Speke had under an apparent misconception named the Kitangule. Stanley during his circumnavigation ascended the mouth of the river and found it to enter the lake about twenty miles further north than was conjectured by Speke. What is, however, of more importance, is the careful exploration of this curious river further up its course, confirming and extending the discoveries previously made by the careful Speke. Speke's Lake Windermere has been found to be only one of a series of at least seventeen lakes, which are in reality one, which are fed and drained by the river Kagera, and which Stanley with considerable reason regards as "the real parent of the Victoria Nile," and along with the Shimeeyu
River on the south, the main feeder of the Victoria Nyanza. Stanley's account of his exploration of this lake-river is of such importance that we shall quote his own words :-

"While exploring the Victoria Lake I ascended a few miles up the Kagera, and was then struck with its great volume and depth-so much so as to rank it as the principal affluent of the Victoria Lake. In coming south, and crossing it at Kitangule, I sounded it and found fourteen fathoms of water, or 84 feet deep, and 120 yards wide. This fact, added to the determined opinion of the natives that the Kagera was an arm of the Albert Nyanza, caused me to think the river worth exploring. I knew, as all do who understand anything of African geography, that the Kagera could not be an effluent of Lake Albert, but their repeated statements to that effect caused me to suspect that such a great body of water could not be created by the drainage of Ruanda and Karagwe, and that it ought to have its source much further, or from some lake situate between Lakes Albert and Tanganyika. When I explored Lake Windermere I discovered, by sounding, that it had an average depth of $40 \mathrm{feet}$, and that it was fed and drained by the Kagera. On entering the Kagera, I stated that it flashed on my mind that it was the real parent of the Victoria Nile; by sounding I found 52 feet of water in a river 50 yards wide. I proceeded on my voyage three days up the river, and came to another lake about nine miles long and a mile in width, situate on the right hand of the stream. At the southern end of this lake, and after working our way through two miles of papyrus, we came to the island of Unyanyubi, a mile and $a$ half in length. Ascending the highest point on the island, the secret of the Ingezi or Kagera was revealed, Standing in the middle of the island I perceived it was about three miles from the coast of Karagwe, and three miles from the coast of Kishakka west, so that the width of the Ingezi at this point was about six miles, and north it stretched away broader, till beyond the horizon green papyri mixed with broad grey gleams of water. I discovered, after further exploration, that the expanses of papyri floated over a depth of from 9 to I4 feet of water, that this vegetation, in fact, covered a large portion of a long shallow lake; that the river, though apparently a mere swift-flowing budy of water, confined seemingly within proper banks by dense tall fields of papyri, was a current only, and that underneath the papyri it supplied a lake varying from five to fourteen miles in width, and about eighty geographical miles in length. Descending the Kagera again some five miles from Unyanyubi, the boat entered a large lake on the left side, which, when explored, proved to be thirteen geographical miles in length by eight in breadth. From its extreme western side to the mainland of Karagwe east was fourteen miles, eight of which was clear open water; the other six were covered by floating fields of papyri, large masses or islands of which drift to and fro daily. By following this lake to its southern extremity I penetrated between Ruanda and Kishakka. I attempted to land in Ruanda, but was driven back to the boat by war-cries, which the natives sounded shrill and loud. Throughout the entire length (eighty miles) the Kagera maintains almost the same volume and nearly the same width, discharging its surplus waters to the right and to the left as it flows on, feeding, by means of the underground channels, what might be called by an observer on land seventeen separate lakes, but which are in reality one, connected together underneath tre fields of papyri, and by lagoon-like channels meandering tortuously enough between detached fields of this most prolific reed. The open expanses of water are called by the natives so many "rwerus," or lakes; the lagoons connecting them and the reed-covered water are known by the name of "Ingezi." What Speke has styled Lake Windermere is one of these "rwerus," and is nine miles 
in extreme length and from one to three miles in width. By boiling point I ascertained it to be at an altitude of 3,760 feet $^{\mathrm{x}}$ above the ocean, and about 320 feet above Lake Victoria. The extreme north point of this singular lake is north by east from Uhimba, its extreme southern point. Karagwe occupies the whole of its eastern side. South-west it is bounded by Kishakka, west by Muvari, in Ruanda, north-west by Mpororo, north-east by Ankori.

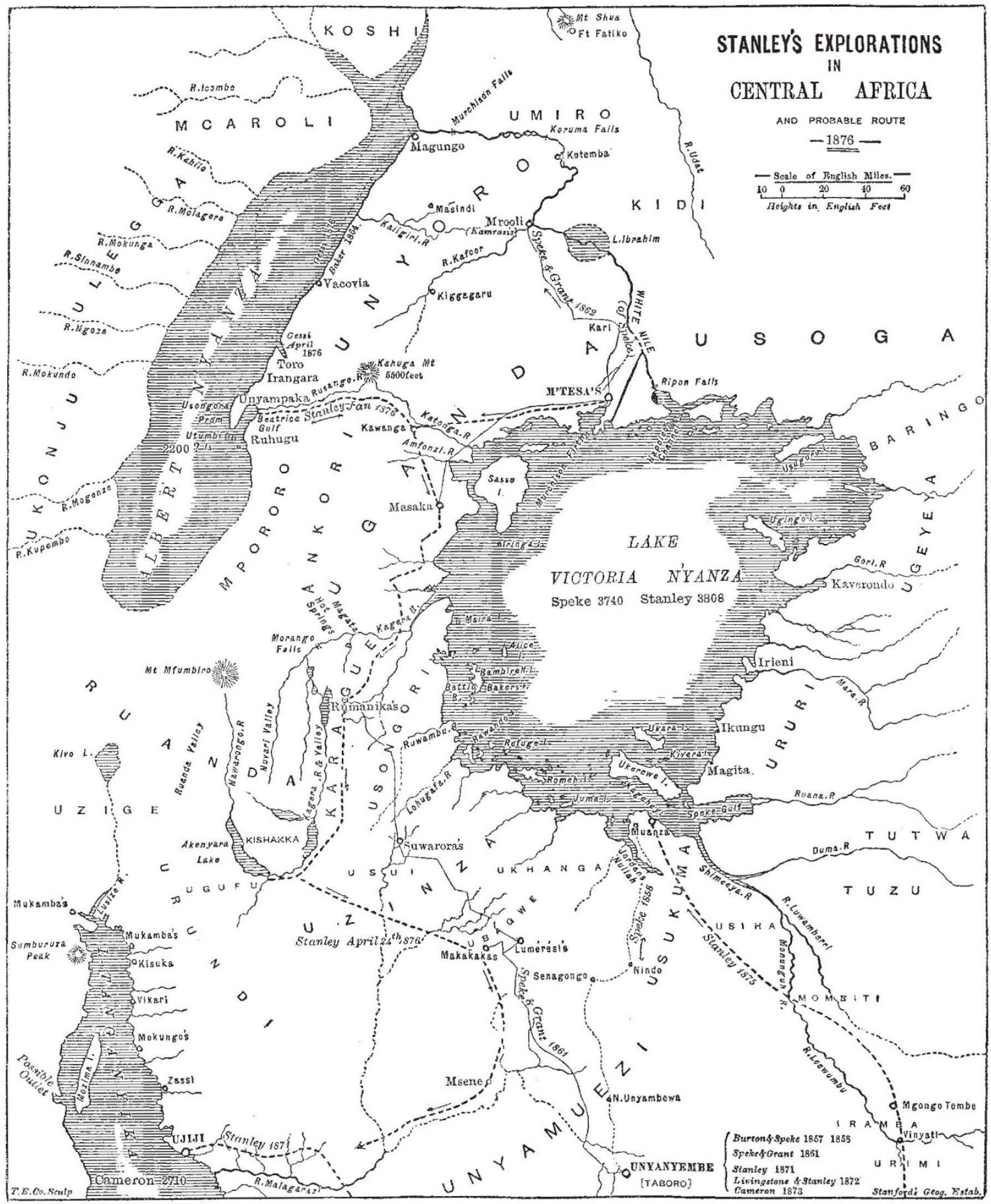

At the point where Ankori faces Karagwe the lake conI. There is evidently an inconsistency between this statement and the height ( 3,800 feet) above given for the Victoria Lake. The latter, however, is Capt. George's computation from Stanley's readings. Stanley's observations
will no doubt be revised when his readings for Lake Windermere are sent home. Meantime we must let his statement stand. tracts, becomes a tumultuous noisy river, creates whirlpools, and dashes itself madly into foam and spray against opposing rocks, till it finally rolls over a wall of rock ten or twelve feet deep with a tremendous uproar-on which account the natives call it Morongo, or the Noisy Falls." 
Mr. Stanley does not exaggerate the importance of this discovery. That the river has any connection with Tanganyika is in the highest degree improbable, as the Victoria into which it drains is more than 500 feet above the level of Tanganyika ; but the question of the connections of this lake Mr. Stanley, we hope, has by this time solved. He afterwards traced the Kagera upwards in a south and west direction, the direction in which trend all the ranges in this region, as, indeed, run all the great ridges, troughs, basins, and valleys from Alexandria to the Nyassa Lakes. In Southern Kishakka, however, a valley struck in from the north-west, through which he found issuing into the Kagera, a large lake-like river called Akanyaru. Above the confluence the Kagera was seen to be a swift-flowing stream of no great depth or breadth. From the Mlagata hot springs Stanley obtained a good view of the region to the north-west, including the Ufumbiro mountains, two sugar-loaf cones and a ridge-like mass, reaching a height of 12,000 feet. From this point of view, also, he saw three other lofty ridges separated by broad valleys. Between two of these ridges flows the Nawarongo river rising in the Ufumbiro mountains, and flowing south by west to join the Akanyaru lake-river. Another large lake he heard of as lying to the westwards, but of this he could obtain no certain information.

Of Stanley's visit to Lake Albert Nyanza little need at present be said, as he succeeded in obtaining only a glimpse of it, when he felt himself compelled to return. Some important observations, however, he did succeed in making, and collected many scraps of information. His statements about "the king of mountains," Gambaragara, and its pale-faced, brown-haired inhabitants, the chief medicine-men of the notorious Kabba Rega, have roused curiosity to the utmost. This mountain, which appears to be situated somewhere on the north of Unyampaka, in height between 13,000 and 15,000 feet, Mr. Stanley conjectures to be an extinct volcano, as "on the top of it is a crystal-clear lake, about 500 yards in length, from the centre of which rises a column-like rock to a great height. A rim of stone like a wall surrounds the summit, within which are several villages, where the principal medicine-man and his people reside." Stanley's route to the Albert Lake was partly through Unyoro and partly through an uninhabited tract of Ankori, his camp being pitched near the edge of the plateau which borders the lake, in the district of Unyampaka. During his march he made important observations on the contour of the plateau which separates the two lakes, the structure of the mountains and ridges, the course of the watersheds and of the rivers Katonga and Rusango. The general correctness of Baker's map, so far as the east coast is concerned, has been confirmed, and although the actual lake may not extend south of the equator, it is probable that there are long stretches of papyrus swamps at its head. The kingdom of Unyoro, under Kabba Rega, occupies a large extent of the eastern shore of the lake, and includes many minor states, the names of which, and of others on the west side, Mr. Stanley succeeded in collecting. The extensive promontory of Usongora, forming Beatrice Gulf, on the shores of which Mr. Stanley encamped, is the great saltfield whence all the surrounding countries obtain their salt, and rumour makes it a land of wonders, with a mountain emitting fire and stones, a salt lake of great extent, hills of salt, and a breed of large savage dogs and longlegged natives. Mr. Stanley gives the latitude of his camp on Lake Albert as $0^{\circ} 25^{\prime} \mathrm{N}$. and longitude $31^{\circ} 24^{\prime} 30^{\prime \prime} \mathrm{E}$. It is difficult to reconcile this last datum with previous observations, and indeed with the length of Stanley's own march between the two lakes. If his own map of Victoria is correct, the two lakes must be within thirty miles of each other. It is probable, we believe, that Sir Samuel Baker's map places the east coast of the lake too far west, and that its position will have ultimately to be changed, but if to so great an extent as is indicated by Stanley's statement, must be solved by further observations. At present we cannot reconcile Signor Gessi's narrative with that of Stanley. Gessi states that he was stopped in his navigation by a "forest of Ambatch," some thirty miles to the north of Stanley's Beatrice Gulf, and that the natives declared the lake extended no farther south. The statements of the two travellers are equally positive, and we have no reason to distrust either, and therefore we can only wait for more information, which, it is likely, will now soon reach us, either from Mr. Stanley or Mr. Lucas, an independent traveller, who is actuated purely by a love of exploration, and who, by last accounts, was on his way to the lake.

On his return from this expedition Mr. Stanley set out southwards through Karagwe for Ujiji, his purpose being, if possible. to reach Lake Albert from the west and make as thorough an exploration of it as he has done of the Victoria Lake. The chances are that he will be successful. It was while in Karagwe that, by the assistance of the hospitable old king Rumanika, he was able to explore the Kagera lacustrine region. On completing this exploration he visited the hot springs of Mlagata, two days' march from Rumanika's capital, in a deep-wooded gorge clothed in the most luxuriant vegetation. These springs reach a temperature of about $130^{\circ} \mathrm{Fahr}$., and are greatly resorted to for their supposed curative effects, which $\mathrm{Mr}$. Stanley seems to doubt.

Mr. Stanley's last letter is dated April 24, I876, from Ubagwe, Western Unyamwezi, fifteen days' journey from Ujiji, which, if all has gone well, he will have reached long ago. Before setting out for Lake Albert again, he proposed to explore the hitherto unvisited portion of the north-west shore of Tanganyika. From this exploration some authorities expect important results to follow; it is indeed thought possible that in this direction will be found the real outlet of Tanganyika, and that Cameron's river Lukuga may ultimately be discovered to be after all only an indentation of the lake, and that moreover a connection will be found between Tanganyika and the Albert Nyanza. However this may be, both explorers have done work of the highest importance in African geography, and the last published letters of Stanley must be regarded as a really valuable contribution to the solution of the great Nile problem and to an accurate knowledge of Central Africa. He has proved himself an explorer of the greatest capability, and the expedition he leads reflects credit on the enterprise and public spirit of the proprietors of the two newspapers who have sent him out.

\section{COFFEE IN CEYLON}

CEYLON is perhaps best known to Europeans through being one of the chief coffee-growing countries in the world, and indeed, after its production of cinnamon, which gives it a position that is quite unique, its chief claims to notice from the ordinary untravelled Englishman are derived from its coffee. The plant is supposed to have been introduced into the island by Arabs from the Pexsian Gulf more than 200 years ago, as there are traditions extant among the Singhalese of its flowers having been offered at the shrine of the sacred tooth of Buddha in Kandy at a remote date. The art, however, of preparing any beverage from its berries was unknown to the natives, or at least unpractised by them until recent times, and it was only in 1827 that the first plantation was opened--by Sir Edward Barnes, the then Governorwith the idea of exporting coffee to the European market. This estate was situated not far from Kandy, and at an elevation of some 1,800 feet above the sea. Thirteen years afterwards the first rush of speculators in coffee occurred, when the average quantity exported was 54,000 